\title{
Uzbek Language
}

National Cancer Institute

\section{Source}

National Cancer Institute. Uzbek Language. NCI Thesaurus. Code C154189.

A T urkic language that is the sole official language of Uzbekistan. 